\title{
FORMATIVE ASSESSMENT OF CRITICAL READING SKILLS IN HIGHER EDUCATION IN RUSSIA IN THE CONTEXT OF EMERGENCY REMOTE TEACHING
}

\author{
Ksenia Antonova, Nadezhda Tyrkheeva \\ St Petersburg University of Economics, Russia \\ St Petersburg University, Russia
}

\begin{abstract}
The paper considers the role of formative assessment of critical reading skills within the framework of distance education in conditions of emergency remote teaching English as a foreign language. A model of descriptors for assessment of critical reading skills at 4 levels of language competence and 3 levels of university education has been developed and tested on undergraduate and postgraduate students majoring in Economics, IT and the Humanities in Saint-Petersburg State University of Economics. The model has been tested and conclusions have been made about the effectiveness of formative assessment as a supplementary/helpful tool for the development of critical reading skills in emergency learning conditions of COVID pandemic.
\end{abstract}

Key words: professionally-oriented learning, formative assessment, summative assessment distance teaching and learning, critical reading, universal and professional competences, critical thinking

\section{INTRODUCTION}

In the context of the sanitary and epidemiological crisis of 2020, when the entire world community is unable to participate in the traditional educational process, the education system is therefore everywhere forced to switch to a new format of education distance (emergency remote) learning. It is a great pedagogical experiment and a challenge for modern education: the restriction of physical presence and direct interaction between the teacher and the student highlighted forms of distance learning previously little used in the framework of traditional education.

Traditionally, it is believed that distance learning is highly attractive (Anderson, 2008; Aston, 2002; McClintock, 1992) since it makes education accessible to those who, for whatever reason, cannot participate in the traditional face-to-face educational process. The general characteristics of distance learning (e-learning) are: separation of the learner and the teacher in space, communication mediated by information and communication technical teaching aids, a high proportion of independent learning and self-control on the students' part.

Submitted December $25^{\text {st }}, 2020$, accepted for publication February $25^{\text {th }}, 2020$

Corresponding author: Ksenia Antonova. Saint-Petersburg University of Economics. 21, Sadovaya street, 191023 St Petersburg, Russia | E-mail: ksana-a@mail.ru 
Being confronted with the emergence situation of online teaching, at the very start of the pandemic the majority of the teaching staff automatically transferred practices of face-to-face teaching and assessment online. Summative assessment results of the spring term showed that the direct move of the face-to-face form of education to distance learning cannot be effective and confirmed the hypothesis that distance education requires profound reconsideration of methodological, pedagogical and psychological approaches to instruction and assessment giving priority to formative assessment as the foundation for building up successful individual paradigm for each particular student. To verify the hypothesis the experiment of formative assessment implementation for evaluating critical reading skills was undertaken in SaintPetersburg State University of Economics among undergraduate and postgraduate students of IT, Economics and Humanities.

During the experiment the question arose of working out criteria and an efficient model of descriptors for formative assessing critical reading skills in the context of a distance teaching EFL, about the search of effective assessment methods format.

We can say that the psychological and pedagogical technologies for assessing the key constructs of the competence-based approach in the professionally-oriented educational process are just beginning to be developed (Definition and Selection of Competencies: Theoretical and Conceptual Foundations, 2001: Definition and Selection of Competencies (DESECO). Theoretical and Conceptual Foundations. Strategy Paper, 2002; Safonova, 2004; Solovova, 2008). In this regard, it seems promising to introduce the experience of researchers on formative assessment for developing effective criteria and a model of descriptors for critical reading evaluation as a part of communicative competence through the experimental research, carried out in digital environment in Saint-Petersburg State University of Economics for teaching students majoring in Economics, IT, the Humanities critical reading of professionally-oriented texts.

\section{FORMATIVE ASSESSMENT THEORY}

The introduction of the term formative assessment (formative evaluation) is ascribed to Scriven (1967), who used to say "formative evaluation... is typically conducted during the development or improvement of a program... and it is conducted, often more than once, for the in-house staff of the program with the intent to improve" (Scriven, 1991, pp. 168-169) unlike summative assessment or evaluation that "is conducted after completion of the program... and for the benefit of some external audience or decision-maker... (Scriven, 1991, p. 340). Since then the focal point of the discussion has been on differentiating formative and summative assessments. A profound insight into assessment theory was made by Benjamin S. Bloom who distinguished formative and summative assessments from the point of purpose, timing and generalisation. According to Bloom, "formative evaluation is ... the use of systematic evaluation in the process of curriculum construction, teaching, and learning for the purpose of improving any of these three processes" (Bloom et al., 1971, p. 117), while the purpose of summative assessment was to grade and certify the learner. Various studies and meta analyses of research data over the past 20 years have developed Bloom's theory and at different times elaborated on the issue of purpose, timing, generalisation as well as conditions for effective feedback and identified positive contribution to the teaching-learning process that efficient combination of formative and summative assessment are supposed to provide.(Wiliam 1998, 2018; 
Bell and Cowie 2001; Brookhart 2008; Guskey 2007; McMillan 2007 and others) because the main purpose of the former is to aid learning while the main aim of the latter is to grade and certify the results.

In the COVID-19 pandemic era we have faced a unique situation when the ultimate purpose of education and the format of instruction are undergoing a profound reconsideration. The primary focus of education has been redirected on soft skill acquisition, whose main task is to develop the individual. Distance teaching that substituted in emergency face-to-face teaching also relies to a great extent of personal characteristics and capacities of the student. Thus, the combination of these two conditions makes us pay additional attention to formative assessment techniques and their regular implementation during the teachinglearning process in order to make the necessary corrections in individual pedagogical approach to a particular student. Quoting Bloom, "the main purpose of formative observations... is to determine the degree of mastery of a given learning task and to pinpoint the part of the task not mastered. ... The purpose is not to grade or certify the learner; it is to help both the learner and the teacher focus upon the particular learning necessary for movement towards mastery". In our experimental research we strived to demonstrate that in conditions of distance learning formative evaluation is supposed to serve as a tool for collecting the evidence about how to improve the curriculum, methodology, as well as individual approach of the teacher and the student in order to avoid failure in summative assessment and make timely corrections of the mostly student-dependant online educational process. Prioritizing formative assessment should reduce the negative effect that is associated with emergency remote education.

We view formative assessment as a tool for teachers and students to shape their own educational route depending on the background, residual knowledge, academic capacities, psychological features, conditions of learning and format of instruction provision. Improving the final results of education is expected as an outcome of effective formative assessment imlementation especially with the new tasks set in front of the education and in the new educational environment.

The possible forms of formative assessments are correspondingly broad. Formative assessment information can be gleaned from information-gathering activities such as traditional classroom tests, but also from observations, oral questioning, class discussions, projects, portfolios, homework, performance assessments, group work with peer feedback, student self-assessment, and other sources.

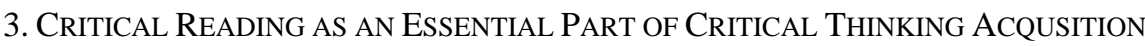 AND CRITERIA OF ITS FORMATIVE ASSESSMENT}

Critical reading is a necessary component for critical thinking and a practice that is crucial for success in academic and civic life (Carillo 2017; Horning 2007). It is conceived from active reading, requiring an activity on the part of the learner (Schwegler 2004). It refers to the awareness of the fact that all texts are crafted objects, written by people with particular dispositions or orientations to the information, regardless of how factual or neutral the products may be (Freebody and Luke 1990). 
We regard "critical reading" as a reading for academic purposes and for academic success which is an ability to go beyond summary of main ideas to analysis, synthesis and evaluation, i.e. the ability to critically comprehend, evaluate, interpret what has been read and apply the results obtained to solve a given problem.

The non-critical reader makes sense of the presentation as a sequence of thoughts, understands the information, ideas, and opinions stated within the text from sentence to sentence, paragraph to paragraph, while the critical reader makes an analytical activity, which is a non-linear process: he reads a text to identify patterns of elements - information, values, assumptions, and language usage - throughout the discussion. It is only when readers struggle with texts that they are likely to become aware of different factors affecting comprehension.

We think that formative assessment can be referred to as a tool that a student needs to be shown how to read more effectively and be explained about their ongoing development as critical readers.

Peter Afflerbach states that effective reading programs combine formative and summative assessment (Afflerbach 2013). Formative assessment is the one that provides up-to-date and detailed information about students' learning in relation to benchmarks. Such assessment is used to help teachers shape or form understanding of students' reading development and training across lessons, units, marking periods, or academic years. We are sure that in the context of emergency remote teaching it is the formative assessment that provides the valid information about the effectiveness of educational process and students' development.

The system of formative assessment of critical thinking skills in reading will be based on the following provisions:

Critical thinking skills in reading:

- is the highest level of development of reading skills;

- is the basis for the formation of the personality of the reader, which in professional life means the ability to study all life;

- acquire special relevance in the context of the information boom, characterized by a sharp increase in information saturation;

- are individual in nature, which means that the reader interprets the author's ideas, guided by his critical point of view.

- are formed sequentially gradually and are based on other types of reading (search, familiarization, study) and correlate with the level of language proficiency from B1 to $\mathrm{C} 2$.

Karen Manarin et al. identify the following characteristics of critical reading for academic purposes:

- identifying patterns of textual elements;

- distinguishing between the main and subordinate ideas;

- evaluating credibility;

- making judgments about how the text is argued;

- making relevant inferences about the text (Manarin et al. 2016)

Thus, we proposed a classification of critical reading skills from B1 to $\mathrm{C} 2$ that scaffold student reading experiences and lead them through the various stages of our critical approach. 
Table 1 Critical reading components and its criteria

\begin{tabular}{|c|c|}
\hline Level & Critical reading components and its criteria \\
\hline \multicolumn{2}{|r|}{ criterion 1: identifying patterns of textual elements } \\
\hline B1 & $\begin{array}{l}\text { - can name contexts and key themes; } \\
\text { - can identify the main ideas and rephrase them in their own words. }\end{array}$ \\
\hline $\mathrm{B} 2$ & $\begin{array}{l}\text { - can obtain information, ideas and opinions from highly specialized sources } \\
\text { within their field; } \\
\text { - can understand specialized articles outside their field, provided they can use a } \\
\text { dictionary occasionally to confirm their interpretation of terminology. }\end{array}$ \\
\hline $\mathrm{C} 1$ & $\begin{array}{l}\text { - can understand in detail a wide range of lengthy, complex texts likely to be } \\
\text { encountered in professional or academic life, identifying finer points of detail } \\
\text { including attitudes and implied as well as stated opinions. }\end{array}$ \\
\hline $\mathrm{C} 2$ & $\begin{array}{l}\text { - can understand logical, causal, temporal or semantic relationships in order to } \\
\text { link parts of the text to one another. }\end{array}$ \\
\hline \multicolumn{2}{|r|}{ criterion 2: distinguishing between the main and subordinate ideas } \\
\hline $\mathrm{B} 1$ & $\begin{array}{l}\text { - can recognize logic connections; } \\
\text { - can identify connections and relationships between the content elements if these } \\
\text { are explicitly referred to in the given text; } \\
\text { - can summarize the text using these elements. }\end{array}$ \\
\hline B2 & $\begin{array}{l}\text { - can identify structural elements of texts and use their functions to understand the } \\
\text { text as a whole; } \\
\text { can identify the main conclusions in specialized articles within and outside their } \\
\text { field. }\end{array}$ \\
\hline $\mathrm{C} 1$ & $\begin{array}{l}\text { - can identify structural elements of lengthy, complex texts likely to be } \\
\text { encountered in professional or academic life and use their functions to understand } \\
\text { the text as a whole; } \\
\text { - can identify the main conclusions of these texts; } \\
\text { - can summarize lengthy, complex texts. }\end{array}$ \\
\hline $\mathrm{C} 2$ & $\begin{array}{l}\text { - can summarize lengthy, complex texts likely to be encountered in professional } \\
\text { or academic life and recognize their implications }\end{array}$ \\
\hline \multicolumn{2}{|r|}{ criterion 3: evaluating credibility } \\
\hline B1 & - can question assumptions. \\
\hline $\mathrm{B} 2$ & $\begin{array}{l}\text { - can focus on connections to disciplines or across disciplines; } \\
\text { can outline an issue or a problem clearly, speculating about causes or } \\
\text { consequences, and weighing advantages and disadvantages of different } \\
\text { approaches. }\end{array}$ \\
\hline $\mathrm{C} 1$ & $\begin{array}{l}\text { - can master the readers' epistemic skills; } \\
\text { - can identify unstated assumptions within lengthy, complex texts likely to be } \\
\text { encountered in professional or academic life; } \\
\text { - knows that authors write for different purposes, that texts can be biased, and that } \\
\text { not everything in print is necessarily "true"; } \\
\text { - - considers potential implications of the abovementioned features. }\end{array}$ \\
\hline $\mathrm{C} 2$ & - - can sift through various forms of rhetoric. \\
\hline
\end{tabular}




\begin{tabular}{|c|c|}
\hline \multicolumn{2}{|c|}{\begin{tabular}{l|l} 
Level & Critical reading components and its criteria \\
\end{tabular}} \\
\hline \multicolumn{2}{|r|}{ criterion 4: making judgments about how the text is argued } \\
\hline B1 & - can understand simple "for" and "against" argu- ments on a particular issue. \\
\hline B2 & $\begin{array}{l}\text { - can recognize the line of argument in the treatment of the issue presented, though } \\
\text { not necessarily in detail; } \\
\text { - can understand the information that is implied, but not explicitly stated in a text. }\end{array}$ \\
\hline $\mathrm{C} 1$ & $\begin{array}{l}\text { - can distinguish separate elements of an argument (assertion, reason, example, } \\
\text { conclusion) in the text; } \\
\text { - can develop a convincing, logical argument (thesis, justification, exemplification, } \\
\text { conclusion). }\end{array}$ \\
\hline $\mathrm{C} 2$ & $\begin{array}{l}\text { - can evaluate } \\
\text { - arguments and their assumptions in the light of existing conditions; } \\
\text { likely to be encountered in professional or academic life. }\end{array}$ \\
\hline \multicolumn{2}{|r|}{ criterion 5: making relevant inferences about the text } \\
\hline B1 & $\begin{array}{l}\text { - can connect the material to other experiences and ideas, whether social, or } \\
\text { personal. }\end{array}$ \\
\hline B2 & $\begin{array}{l}\text { - can summarize a wide range of factual and imaginative texts, commenting on and } \\
\text { discussing contrasting points of view and the main themes. }\end{array}$ \\
\hline $\mathrm{C} 1$ & $\begin{array}{l}\text { - can connect the material to other experiences and ideas, whether academic, social, } \\
\text { or personal. }\end{array}$ \\
\hline $\mathrm{C} 2$ & $\begin{array}{l}\text { - can summarize information from different sources, reconstructing arguments and } \\
\text { accounts in a coherent presentation of the overall results; } \\
\text { - can use the text for personal self-reflection. }\end{array}$ \\
\hline
\end{tabular}

\section{FEEDBACK AND OUTCOMES OF FoRMATIVE AsSESSMENT OF CRITICAL READING IN DISTANCE LEARNING}

Consideration of formative assessment within the framework of distance learning causes a change in vectors, namely, strengthening independent work and responsibility of students for their learning outcomes, since it is formative assessment that makes it possible to evaluate the learning process in an educational digital environment, taking into account the possibility of building a personal individual route of education / self-education.

The main feature of formative assessment is regular, not evaluating, but correcting feedback: the results of the controlling event, as an indicator of the student's performance, are extracted, interpreted and lead to the action which, in its turn, leads to optimization (improvement) of the learning process

As the assessment expert Dylan Wiliam writes in Embedded Formative Assessment, Second Edition, when educators integrate formative assessment practices into teachers' minute-to-minute and day-by-day classroom activities, substantial increases in student achievement - roughly between 50 to $70 \%$ increase in the speed of learning — are possible (Wiliam 2018). 
The methodological potential of formative assessment is fully realized within the framework of considering the continuity of education: it is formative assessment that will help the teacher and the student to form an effective pathway and smooth out irregularities caused by different educational routes of students during the transition from one stage to another in the higher education system (from undergraduate to graduate school).

It is often valuable to develop learning intentions jointly with students - a process that is sometimes called co-construction. Thus students become owners of their own learning and teachers' collaborating on learning intentions and success criteria helps to ensure that all students in the grade are learning the same thing regardless of the teacher they have.

It seems obvious that students' feedback about their work should help them learn, but it turns out that providing effective feedback is far more difficult than it appears. There are different types of feedback from praise or reprimand to grades or scores. These days teachers can use engineering principles to test the efficiency of their feedback, typical student reactions to feedback, how feedback functions formatively, and principles of effective feedback.

Constructive feedback, as Embedded Formative Assessment defines it, includes specific comments on errors, suggestions to the students about how to improve, and at least one positive remark. Feedback has the power to improve emergency remote learning (Wiliam 2018).

Generally, a student may respond in the one of the following four ways when the feedback indicates that current performance falls short of the goal. 1. The student may change the goal. 2. The student may abandon the goal altogether, which is seen as the learned helplessness of students who face repeated indications that they fall short. 3. The student may reject the feedback. This is quite common in workplace settings when, for example, someone who feels he contributes well beyond what was expected gets a neutral evaluation from a supervisor. 4. The student may change behavior so as to increase performance to match the goal, which is presumably the response the person giving feedback intends.

In most cases ineffective assessment methods are being used that are not capable of giving meaningful feedback regarding each student. Thus, it is not possible to construct a separate learning path for each student in order to successfully complete the learning objectives.

\section{Methodology}

\subsection{Participants}

There were 135 participants in the study (74 Females). 6 study groups were formed by sample random sampling consisting of 20-25 learners each. They were students enrolled on Bachelor (2 groups), Master (2 groups) and Post graduate ( 2 groups) programs in one higher education institution (University) in Russia.

We applied the formative assessment of critical reading at three levels of education throughout spring and autumn semesters of 2020. Even though the goals and requirements for each level were different, they all aimed to promote the formative assessment of critical reading.

All the participants majored in different fields and were taught by the same teacher. 


\subsection{Materials}

In spring 2020

In the context of emergency remote teaching traditional face-to-face teaching methods and teaching materials were used but they were communicated to the groups via information and communication technical teaching aids, in particular by Moodle. Assessment of critical reading skills at three levels of education (bachelor's, master's, postgraduate studies) were performed during the synchronous courses via video conferencing. At the end of the semester all the students passed an exam which included a task for checking critical reading skills according to the criteria mentioned in Table 1, which comprised of the following assessment interview questions: How does this text relate to your research question? $\bullet$ How does this text relate to your experiences? $\bullet$ How does this text relate to other sources that you have read? $\bullet$ Do you agree or disagree with the main idea of the text?

- Does this text make you think about your topic differently than you did before?

We used qualitative methods to analyze various types of data: 1) responses to a task of critical reading comprehension and translation of professionally-oriented texts; 2) five semi-structured interviews focused on the reading task.

In autumn 2020

The participants had the same task activities during of remote teaching and were proposed to read texts according to the level of their language competence and their scientific field. At the same time the formative assessment was organized asynchronously. The students fulfilled tasks about the text and were given the feedback via the computer system Moodle. The computer-mediated feedback was conceived as a personal process-oriented feedback (i.e. feedback on the process and its results of each student). We used two types of feedback: "correct answer" feedback and the "explanation" feedback.

\section{RESULTS}

The aim of the present research was to investigate beneficial effect of formative assessment on acquiring critical reading skills within the framework of emergency remote learning. Agreeing with the majority of scholars about technical, methodological and psychological peculiarities of on-line teaching-learning process we drew a special attention to the type of assessment and prioritized it among the key factors of the students' success in developing skills of critical reading professionally-oriented texts.

Fig. 1 shows that most students were able to comprehend a professionally-oriented text at a minimal benchmark level. Most students were able to understand the text explicitly well enough to identify information and to make at least some inferences about context. The findings showed that most of the students failed to understand the text critically and that this was due mainly to the lack of awareness of critical reading skills and inefficient use of critical reading strategies during the remote classes. Thus, we observe that students demonstrated very low level of performing critical reading skills 
PERFORMANCE LEVEL, SPRING 2020

E bachalors $\equiv$ masters E post graduates students

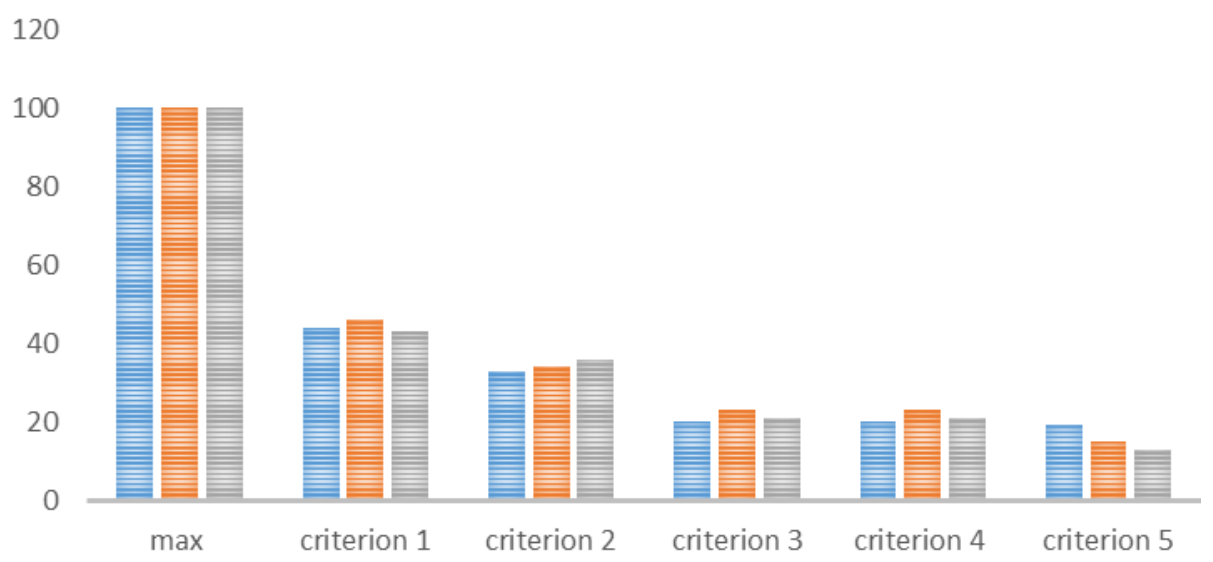

Fig. 1 Performance level, spring 2020

Fig. 2 shows the result of teaching critical reading followed by the formative assessment of critical reading. The system of formative assessment plus feedback had a statistically significant positive effect on critical reading performance in comparison with traditional reading methods and no feedback. Thus, we observe that students demonstrated very different level of performing critical reading skills.

PERFORMANCE LEVEL, AUTUMN 2020

E bachalors 트 masters 르 post graduates students

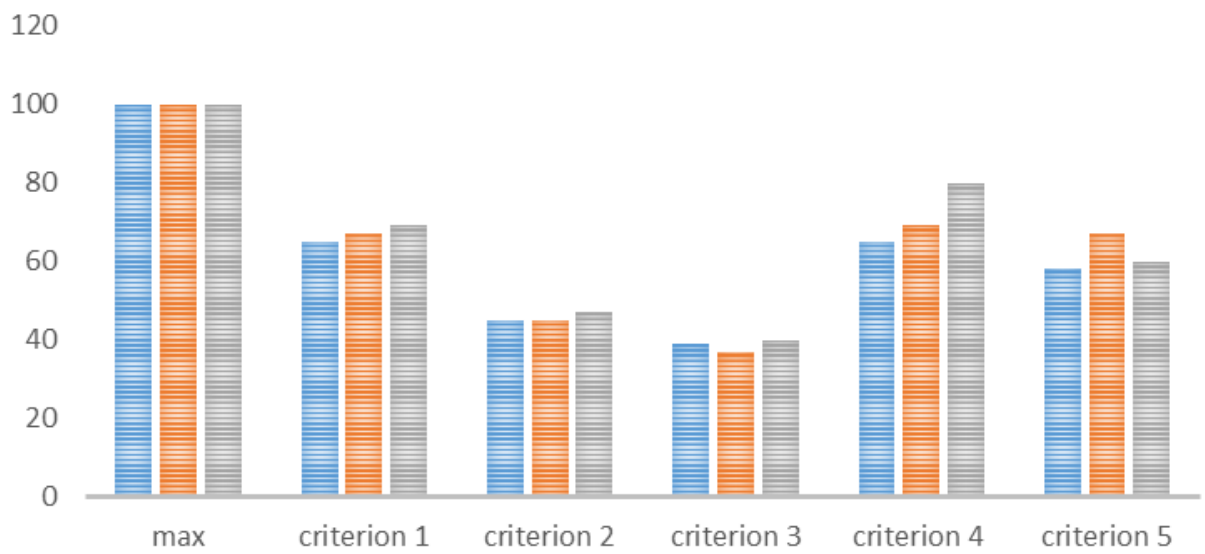

Fig. 2 Performance level, autumn 2020 
We have to admit that effectiveness of different types of feedback remained beyond the scope of this study. We will continue to study the impact of positive feedback on formative assessment effectiveness.

\section{DISCUSSION}

The learning outcomes showed that when reading professionally-oriented texts, students faced different difficulties caused by insufficient (low) formation of critical reading skills:

- identifying patterns of textual elements;

- distinguishing between the main and subordinate ideas;

- evaluating credibility;

- making judgments about how the text is argued;

- making relevant inferences about the text.

Students were not aware of the importance of critical reading or of the difficulties of this activity.

Not all the students identified their problems of literal comprehension of concepts even those who used multiple online resources, such as monolingual dictionaries, bilingual dictionaries, initial and abbreviation dictionaries, linguistic forums.

The most important differences among the students specially remained on the strategies used to detect those comprehension problems of identifying patterns of textual elements; distinguishing between the main and subordinate ideas; evaluating credibility. Some students could not identify the main ideas and rephrase them in their own words as well as they couldn't understand logical, causal, temporal or semantic relationships in order to link parts of the text to one another.

Some students did not check whether their interpretations were correct; this fact made them select wrong / contradictory answers

Some students did not identify the text ideology and did not know what strategies could be used to do so. As a result, problems regarding literal comprehension occurred.

During the interviews the students ignored or had difficulties explaining the actions they performed to find, select and evaluate the text information. On the whole, the students showed different strategies and levels of awareness regarding the importance of evaluating information.

Due to the emergency of transition on-line the teacher simply transferred the traditional forms of oral feedback into distance format, which led to the following problem: the oral feedback sometimes was not really effective for the students because many students did not retain what had been said by the teacher. Consequently, the feedback could not be used by the students for improvement of their study as they simply forgot what the feedback was about. Moreover, the interviews indicated that the feedback given to the students was merely about how to improve their learning strategy to get a high score in final exam. In order to eliminate these difficulties, in the framework of the experiment the teacher offered various types of feedback (oral, written, self-assessment, peer-check), which appeared efficient in the subsequent interviews with the students.

Taking into account everything mentioned above, formative assessment administration proves to be not only useful to find out the students' problems in learning, but it is also essential for the teachers themselves to improve their teaching styles so that learning activities can become more effective in enhancing the students' knowledge and skills. In 
this study since the emphasis was on learning rather than teaching, all courses were conducted by one teacher. Therefore, this does not remove the issue of professional training of teachers for the introduction and use of assessment in the educational process.

\section{CONCLUSION}

The results of this study provide support for the use of formative assessment for critical reading. The participants who were surveyed by means of formative assessment and received corrective feedback solved problems more effectively at the end of autumn semester 2020 than in spring 2020. We formulated the two positive statements surrounding the formative assessment of critical reading skills: formative assessment being assessment for learning provides a sense of lifelong learning; this form of feedback had a statistically significant effect on participants' performance.

Therefore, it is thought that the formative assessment can increase and develop the critical reading skills. Formative assessment should be given more attention to in online teaching.

Activities should be prepared in accordance with the principles of formative assessment and following the strategies of FA

We believe that our framework incorporating the five critical reading elements can help students become active readers and, as a result, active learners.

We hope that the results of this research will contribute to the development of education and shed light on the challenges of the new epoch and ways of dealing with them.

As the discussion is now circling around the question if it will ever be possible to do without summative assessment at all because of its unfavorable psychological impact on the students especially during the exams and other testing procedures. The next step in the development of the assessment issue may consist in determining efficient formativesummative assessment ration in conditions of distance and blended teaching as well as working out criteria for formative assessment of other professional communication skills apart from critical reading like academic and business presentation, writing a scientific paper, abstract and annotation including correspondence in various types of professional networks.

\section{REFERENCES}

Afflerbach, Peter, Byeong-Young Cho, Jong-Yun Kim, Maria Elliker Crassas, Brie Doyle Reading. "What Else Matters Besides Strategies and Skills?" The Reading Teacher no. 66 (6) (2013): 440-448.

Anderson, R. (2008), Implications of the Information and Knowledge Society for Education, In Knezek, G., Voogt, J. (Eds.). Internationa Hanbook for IT in Secondary Education. Springer, 2008. pp. 5-22 [2]

Andrade, Heidi, Gregory J. Cizek. Handbook of formative assessment. New York: Taylor \& Francis Group, 2009.

Aston, M. (2002), The Development and Use of Indicators to Measure the Impact of ICT Use in Education in the United Kingdom and other European Countries, Proceedings of the UNESCO Consultative Workshop for Developing Performance Indicators for ICT in Education, 1st, Manila, the Philippines, 28-30 August 2002, http://www2.unescobkk.org/ elib/publications/ICTindicators/ICTindicators.pdf 
Bell, Beverly, Bronwel Cowie. "The characteristics of formative assessment in science education," Science Education, no. 85 (5) (September 2001): 536-553.

Black, Paul J., Dylon Wiliam. "Assessment and classroom learning." Assessment in Education: Principles, Policy, and Practice, no. 5(1) (1998): 7-73.

Bloom, Benjamin S., Thomas Hastings, George Madaus Handbook of formative and summative evaluation of student learning. New York: McGraw-Hill, 1971.

Brookhart, Susan M. How to give effective feedback to your students. Alexandria, VA: Association of Supervision and Curriculum Development, 2008.

Definition and Selection of Competencies: Theoretical and Conceptual Foundations (DeSeCo) (December 2001). Background Paper. Retrieved from: http://www.oecd.org/ education/skills-beyond-school/41529556.pdf

Definition and Selection of Competencies (DESECO). Theoretical and Conceptual Foundations. Strategy Paper. (October 2002). Organisation for Economic Co-operation and Development. Retrieved from: http://deseco.ch/bfs/ deseco/en/index/02. parsys.34116.downloadList.87902.DownloadFile.tmp/oecddesecostrategypaperdeelsaedcericd20029.pdf

Guskey, Thomas R. Formative classroom assessment and Benjamin S. Bloom: Theory, research, and practice. In J. H. McMillan (Ed.), Formative classroom assessment: Theory into practice. New York: Teachers College Press, 2007: 63-68.

Horning, Alice. "Reading across the curriculum as the key to student success." Across the Disciplines, no. 4, May 14, 2007. <https://wac.colostate.edu/docs/atd/articles/horning 2007.pdf $>$ (30 November, 2020).

Karen Manarin, Miriam Carey, Melanie Rathburn, \& Glen Ryland. Critical Reading in Higher Education: Academic Goals and Social Engagement. Indiana University Press, 2016.

McClintock, R. (1992a), Power and Pedagogy: Transforming Education through Information Technology, Institute of Learning Technologies, New York

Safonova, V. V. (2004). Kommunikativnaya kompetentsiya: sovremennyie podhodyi $k$ mnogourovnevomu opisaniyu v metodicheskih tselyah. Moskva: Evroshkola.

Solovova, E. N. (2008). Metodika obucheniya inostrannyim yazyikam. Bazovyiy kurs. Moskva: AST, Astrel.)

The handbook for embedded formative assessment. Bloomington, IN: Solution Tree Press, 2018.

Wang, K.H., Wang, T.H., Wang, W.L. \& Huang, S.C. "Learning Styles and Formative Assessment Strategy: Enhancing Student Achievement in Web-Based Learning." Journal of Computer Assisted Learning, 22(3), $2006<\mathrm{https}$ ://www.learntechlib.org/p/98836/>(30 November 2020)

Wiggins, Grant. "Seven keys to effective feedback," Educational Leadership, no. 70 (1) (2012): 10- 16.

Wiliam, Dylan. Embedded formative assessment (2nd ed.). Bloomington, IN: Solution Tree Press, 2018. 